Introduction | Special Issue

\title{
Introduction to the Kritike Special Issue: Critical Theory at the Margins
}

Paolo A. Bolaños

$\mathrm{F}$ ounded in 2007, a group of alumni from the philosophy program of the University of Santo Tomas decided to name what would then become the official open-access journal of the Department of Philosophy as Kritike: An Online Journal of Philosophy. The word 'kritike' comes from the Greek verb koiveıv ('krinein'), which means 'to discern.' Hence, kritike means 'the art of discerning' or 'the art of critical analysis.' Any form of philosophizing is, in one way or another, a 'critique' of something. Being critical, therefore, is an attitude common to all philosophical traditions. Indeed, the meaning of philosophy is critique and to be philosophical is to be critical.

The journal, since its inception, has been a staunch advocate of critique. Owing perhaps to the spirit of no less than Theodor Adorno himself who proclaimed that "[c]ritique alone, as the unity of the problem and its arguments, not the adoption of received thesis has laid the foundation for what may be considered the productive unity of the history of philosophy," 1 we may surmise that now more than ever, and especially in today's fastpaced world, perhaps a reversal of Marx's proposition is needed: that the task of the philosopher is not only to actively change the world, but to critically interpret it.

In celebration of the $10^{\text {th }}$ anniversary of the journal, the Department of Philosophy of the University of Santo Tomas hosted the first Kritike Conference on 1-2 December 2017, with the theme "Critical Theory at the Margins." Max Horkheimer understands critical theory as propounding a strong social and political claim: emancipation from slavery and the abolition of social injustice. ${ }^{2}$ Critical theorists have always been staunch defenders of social justice and egalitarianism through their vocal criticisms of the

1 Theodor Adono, "Why Still Philosophy," in Critical Models: Interventions and Catchwords, trans. by Henry W. Pickford (New York: Columbia University Press, 2005), 8.

2 See Max Horkheimer, "Traditional and Critical Theory," in Critical Theory: Selected Essays, trans. Matthew J. O'Connell (New York: Continuum, 1989).

(c) 2019 Paolo A. Bolaños

https://www.kritike.org/journal/special issue/bolanos april2019.pdf

ISSN 1908-7330

(cc) BY-NC-ND 


\section{INTRODUCTION}

ideological nature of capitalist culture and the oppressive tendencies of Western empires. While the birthplace of critical theory is Europe, its normative claims are, nonetheless, universal, inasmuch as it lends an intellectual voice to the voiceless and articulate a notion of hope for the hopeless. ${ }^{3}$ To quote a line from Walter Benjamin's "Goethe's Elective Affinities": "Only for the sake of the hopeless ones have we been given hope." 4

In the context of the Philippine society, critical theory may play an instrumental role in analyzing social and political pathologies. Moreover, the complex history of the Philippines, as a postcolonial nation with a neocolonial culture, has resulted in "marginal spaces" that profoundly inform Filipino identity and culture. As such, the Philippines is a peculiar locus for the possibility of a critical theory of society that is characterized by marginal spaces. While we may understand the word "marginal" in its negative form, usually referring to the disadvantaged members of society, it is also possible to construe "marginal" precisely as the obverse of the disadvantaged, as there are subterranean cultures that are thriving, yet largely unrecognized or misrecognized. These subterranean cultures or "alternative rationalities," when given voice, may inspire new forms of normative modalities that could respond to various forms of social and political crises, thus instigating the possibility of hope and the activation of utopian visions. This special issue of Kritike brings together a collection of selected papers from the conference, exemplifying critical theory, as described above, at work in the Philippine context.

In the first paper, "Problematizing Critical Theory: Arriving at a More Critical Critical Theory," Agustin Martin G. Rodriguez admonishes Filipino scholars who use critical theory as if it provides a set of scientific criteria to test or show the failures of elections, poverty alleviation, or peace processes. Moreover, Rodriguez maintains that, while critical theory has been a helpful tool for critique, it is still nonetheless framed within Western lenses and, as such, in the context of Philippine realities, critical theory lacks "the deep critique of society that unearths the ground which supports the naiveté of Western man's global world building." For instance, Habermasian discourse theory "already legitimizes Western, male rationality and delegitimizes the other rationalities especially those who are known as traditional, tribal, or metaphysical." As such, when applied to local problems

${ }^{3}$ For an elaboration of these normative claims, see Paolo Bolaños, "What is Critical Theory? Max Horkheimer and the Makings of the Frankfurt School Tradition," Mabini Review, 2:1 (2013), 1-19.

4 Walter Benjamin, "Goethe's Elective Affinities," trans. by Stanley Corngold, in Selected Writings: Volume 1, 1913-1926, ed. by Marcus Bullock and Michael Jennings (Cambridge, MA, Harvard University Press, 2004), 356.

(C) 2019 Paolo A. Bolaños

https://www.kritike.org/journal/special issue/bolanos april2019.pdf

ISSN 1908-7330

(cc) BY-NC-ND 
in the Philippines, Habermasian discourse takes the form of a prescription for political or social reform which favors "Western educated rationalities." In contrast to Habermasian discourse theory, Rodriguez explores an alternative critical theory of society grounded in "indigenous forms of inquiry." For Rodriguez, the legitimacy of critical indigenous discourse is not simply the justification of indigenous terms, but, rather, the intellectual articulation of "the value of their forms of knowing on their own terms." A more critical critical theory then demonstrates the epistemic value of "alternative rationalities," that is to say, their own peculiar ways of meaning-giving. To quote Rodriguez: "These alternative meaning giving systems could allow for the most authentic critique of the dominant rationality which critical theory fundamentally seeks to realize." The works of Salazar, Ileto, Almario, and Nono, Rodriguez argues, are notable examples of indigenous critical theory.

Meanwhile, Ranilo B. Hermida's "Towards a Critical Theory of Philippine Society" may be read as a direct contrast to the position of Rodriguez. While, on the one hand, Rodriguez criticizes Habermas for his Western-centric discourse, Hermida, on the other hand, rehearses in detail the basic presuppositions of Habermas' theory of communicative action: from the critique of positivism, to the emphasis of the normative import of human interests, down to the procedural workings of communicative rationality. Hermida, then, uses this Habermasian framework to articulate a vision of a "critical theory of Philippine society." This localized critical theory, according to Hermida, necessitates a reevaluation of the significance of philosophy more specifically, "we must reflect on the study and teaching of philosophy in our country." This reevaluation entails factoring in the historical upheavals that shaped Philippine society in the past three decades (the three people power revolts) for they, as Hermida intimates, reflect the nuances of our societal problems and how we have collectively responded to these problems. This reevaluation of philosophy, moreover, entails a rethinking of the role of philosophy courses in the various curricula offered in schools and universities. Is philosophy taught as primum inter pares or unum inter pares? Are we teaching philosophy in the spirit of communicative interdisciplinarity? Do our philosophy courses address issues regarding the oppressive tendencies of our educational and economic systems? In other words, we must be able to teach philosophy in such as a way that theory and practice are combined. Hermida notes that Habermas is a philosopher that exemplifies that union of theory and practice, inasmuch as the latter wrote against the backdrop of historical events in Europe. In this context, philosophy can only become relevant if its center is the present historical situation, that is to say, when it engages with the public sphere of reason.

Jeffry V. Ocay offers the third paper of this special issue, "The Peasant Movement and Great Refusal in the Philippines: Situating Critical Theory at

(c) 2019 Paolo A. Bolaños

https://www.kritike.org/journal/special issue/bolanos april2019.pdf

ISSN 1908-7330

(cc) BY-NC-ND 


\section{INTRODUCTION}

the Margins," where he explores an underdeveloped dimension of Herbert Marcuse's work: the nature of social struggles at the margins. Ocay uses Marcuse's notion of the Great Refusal as an interpretative tool for critically understanding the plight of peasant movements in the Philippines. More specifically, Ocay underscores "the possibility of redemptive alternatives to the struggle for emancipation." I take as the most novel contribution of this piece, which is actually the centerpiece of the theme of the conference, the idea that "the most oppressed of the oppressed" offers the hope for emancipation. Ocay shows that "Filipino peasants in their plight, but also in their organization and indeed in their struggles, point to a way of life that escapes the apparently inescapable logic of technological domination." Peasant movements, according to Ocay, while they are dominated by the neoliberal system, actually exist "outside the established" system, thereby highlighting the violence inflicted upon their societies inasmuch as these movements of "ways of life" are not completely contained by the dominant system. Moreover, as peculiar ways of life, they provide utopian visions for alternative ways of organizing society. Ocay, however, is very specific, as not all peasant groups in the Philippines, such as the lowlanders, qualify to be agents of emancipation. The agents of social transformation are from the periphery, the margins, "upland agricultural areas where they produce agricultural products for the local economy and for family consumption." Ocay, moreover, argues that, while some radical peasant movements have resorted to militant struggle, what the paper intends to do is to present alternative practices of resistance that do not resort to violence. One example of nonviolent resistance is the practice of communitarian cooperation which is a more viable system of shared labor and economic organization. Ocay's piece forces us to ask question whether the margins need critical theory or, rather, critical theory actually needs the normative resources of the margins in order for critical theory to make sense.

In the fourth paper, "Becoming-Democratic as BecomingRevolutionary," Raniel SM. Reyes explains how Gilles Deleuze- and Felix Guattari's notion of "becoming-minoritarian" becomes a normative basis for "becoming-revolutionary." One aspect of becoming-monoritarian, according to Reyes, is "becoming-democratic." Deleuze and Guattari's notion of becoming-democratic is, however, in opposition to conventional democratic practices, as it "exemplifies the principle of becoming-revolutionary via its critical diagnosis of different capitalist and democratic codifications in the society." Reyes defends Deleuze and Guattari from accusations of being apolitical and maintains that what they offer is a minoritarian notion of democracy that emphasizes its critical potential, as opposed to it being a majoritarian (or grand) political theory. As such, for Reyes, Deleuze and Guattari present democracy as a kind of minoritarian praxis, that is to say, a

(C) 2019 Paolo A. Bolaños

https://www.kritike.org/journal/special issue/bolanos april2019.pdf

ISSN 1908-7330

(cc) BY-NC-ND 
kind of praxis that happens in specific, and often personal or subjective, moments that are dialectically conditioned by majoritarian narratives. To be more exact, "Minoritarian politics aspires to critically examine how laws are created and interpreted, and how minoritarians can challenge majoritarian principles in society so as to produce novel laws and relations." In this context, therefore, minoritarian politics is close to jurisprudence inasmuch as jurisprudence is the "creative modification of existing laws and rights to address varying and present circumstances." This critical-creative character of becoming-democratic is the revolutionary potential of minoritarian politics - it is a becoming that perpetually opens up the invention of new types of resistance. There is an attempt by Reyes, albeit almost implicitly, to recommend this Deleuze-Guattarian minoritarian critique of majoritarian politics in the Philippines, more specifically the strands of anti-intellectualism and populism in the realms of education and politics.

"Toward an Aesthetic Community: A Manifesto for a Revolution to Come" is the fifth piece, where its author Jesus Emmanuel S. Villafuerte, by borrowing some insights from Adorno, presents a critical assessment of the "artist's perception of his superiority and offer ways on how he could reformat his modes of thinking and making." Villafuerte's premise is that the privilege accorded to the artist in society today renders a kind of forgetfulness the materiality of art. In effect, the artistic creation, as well as the artist himself or herself, becomes immune to the "exigencies of class conflict" and the "politics and ideology" that come with its production. Along with this forgetfulness of materiality of the artwork, Villafuerte adds the artwork's "original ethico-representative logic" is also veered away from. By discussing the historical circumstances that led to the veneration of the artist and the birth of the curator, "the prophet of the museums and galleries," Villafuerte tells a story about the fetishizing logic of capitalism that developed in the world of art, that is, the world of artists and curators. Villafuerte, however, salvages the image of the curator: "a curator ... is self-reflexive ... someone who is aware of the inherent contradictions in his role and power ... by virtue of his awareness ... able to subvert the logic imposed on him ...." In addition to salvaging the curator, Villafuerte, recasts the role of the artist. He argues that the artist (as well as the curator) will only be able to become significant again if he/she subverts the fetishizing logic of capitalism that haunted the artworld. Inspired by Rancière, the artist, Villafuerte intimates, "must leave the museums and galleries and forge connections with the common people" leading to the "creation of an aesthetic community."

The final paper for this special issue is Franz Giuseppe F. Cortez's "Ang SMisasyon ng Lipunang Pinoy." Cortez introduces the neologism, "SMisasyon" or "SMization," which he argues as the Philippine version of phenomena, such as, McDonaldization, Disneyfication, and Wal-Martization.

(c) 2019 Paolo A. Bolaños

https://www.kritike.org/journal/special issue/bolanos april2019.pdf

ISSN 1908-7330

(cc) BY-NC-ND 


\section{INTRODUCTION}

He defines SMisasyon as "the effective perpetuation and fortification of the neoliberal process in the Philippines and the broadening of its effect in all aspects of the lives of Filipinos ..." For Cortez, SM (Shoe Mart) is a conglomerate that symbolizes the dominance of the neoliberal ideology in the Philippines, inasmuch as the SM symbol and values penetrate various aspects of Philippine society: economic, social, religious, political, cultural, psychological, moral, ecological, inter alia. In the paper, Cortez explores three features of SMisasyon: hyper-consumerism, survival-of-the-fittest culture, and myth of upward mobility. According to Cortez, the shopping mall is the physical manifestation of hyper-consumerism and SM malls exemplify exactly this. The mall projects the illusion of affluence and paints a misleading image of Philippine society. The display of infinite consumer goods, available to people from all walks of life, masks the reality of poverty and projects a pretentious appearance of a well-ordered society. Moreover, SMisasyon, according to Cortez, had changed the behavior of way of life of Filipinos who have assumed the philosophy of "survival of the fittest" through consumption or, at least, the appearance of consumption. Cortez intimates that, while the consumer culture presents a scenario where people can participate in a leveled playing field; in reality, this culture is governed by the dialectics between the powerful and the weak. At the end, the invisible hand behind the pretense of affluence and fairness is still monopoly capitalism. The last point of Cortez is that SMisasyon breeds the culture of "upward mobility," that perseverance and patience lead to gain. Cortez complains that in SMisasyon, the ideologues of neoliberalism determine the purpose of perseverance and patience. Indeed, neoliberalism is the new religion and the shopping malls are the new religion's cathedrals.

Finally, I wish to acknowledge the institutions and people who made the conference and the publication of this special issue possible. The Commission on Higher Education granted us the necessary financial assistance to organize the conference and to fund the publication though the CHED Journal Challenge Program. Additional institutional support was provided by the University of Santo Tomas, through the Department of Philosophy, Faculty of Arts and Letters, as well as the Ecclesiastical Faculty of Philosophy. I also wish to take advantage of the opportunity to thank the Editorial Team for this special issue: RT Pada, Jovi Cariño, Raniel Reyes, Ranier Abengaña, Gian Agbisit, Julia de Castro, and Venus Basa.

Department of Philosophy, University of Santo Tomas, Philippines

(C) 2019 Paolo A. Bolaños

https://www.kritike.org/journal/special issue/bolanos april2019.pdf

ISSN 1908-7330

(cc) BY-NC-ND 


\section{References}

Adorno, Theodor, "Why Still Philosophy," in Critical Models: Interventions and Catchwords, trans. by Henry W. Pickford (New York: Columbia University Press, 2005).

Bolaños, Paolo, "What is Critical Theory? Max Horkheimer and the Makings of the Frankfurt School Tradition," Mabini Review, 2:1 (2013).

Benjamin, Walter, "Goethe's Elective Affinities," trans. by Stanley Corngold, in Selected Writings: Volume 1, 1913-1926, ed. by Marcus Bullock and Michael Jennings (Cambridge, MA, Harvard University Press, 2004).

Horkheimer, Max, "Traditional and Critical Theory," in Critical Theory: Selected Essays, trans. Matthew J. O'Connell (New York: Continuum, 1989). 